\title{
THE JURISDICTION OF THE FEDERAL COURTS BASED ON DIVERSITY OF CITIZENSHIP
}

\author{
ROBERT C. Brown
}

A bill ${ }^{1}$ introduced by Senator Norris, the chairman of the Senate Judiciary Committee, proposes to amend Section 24 of the Judicial Code ${ }^{2}$ by striking out the provisions for suits "between citizens of different states", thus completely abolishing the jurisdiction of the federal courts based upon the diversity of citizenship as between the states of the litigant. ${ }^{3}$ Despite the vigorous opposition of the American Bar Association and various other professional bodies, the bill has been favorably reported by the committee, but has not yet come to a vote in the Senate. The committee has been justly criticized by the American Bar Association for reporting the bill without adequate notice to the profession and without any subsequent opportunity for a hearing of objections. ${ }^{4}$ Nevertheless, this is, of course, no proof that the bill is undesirable; and, in fact, it has had vigorous support from wellknown authorities upon the subject. ${ }^{5}$

The purpose of this article is to examine the desirability of this very important branch of federal jurisdiction, and, in consequence, to consider the desirability of its complete abolishment as provided in the Norris Bill.

\section{Constitutionality}

The question of the constitutionality of the proposed measure perhaps merits the first consideration, since it has been attacked on this very ground by President Newlin, of the American Bar Association. ${ }^{6}$ Of course, if the act is unconstitutional, it should

${ }^{2}$ S. 315I, joth Congress.

${ }^{2} 36$ STAT. IO9I (I9II), 28 U. S. C. $\$ 4$ T, par. I (I928).

s The bill also proposes the abolition of other bases of jurisdiction, including even that based upon federal questions; but this is outside the scope of the present discussion.

'See the report of the Committee on Jurisprudence and Law Reform (I928) 53 A. B. A. REP. 425.

'Frankfurter, Distributions of Judicial Power betzween United States and State Courts (1928) i3 CoRN. L. Q. 499.

aNewlin, Proposed Limitations Upon our Federal Courts (Ig29) is A. B. A. J. 40I, 
be immediately rejected on that ground, without consideration of its desirability.

It is believed, however, that the objections to the constitutionality of the bill cannot be sustained. The jurisdiction based on diversity of citizenship is, of course, provided for in the Constitution ${ }^{7}$ as definitely as any other branch of federal jurisdiction. This is the basis of Mr. Newlin's contention, but in order to sustain it one would have to argue that it is the duty of Congress to invest the lower federal courts with all jurisdiction which the Constitution permits such courts to have. Indeed, there is a dictum to that effect by Mr. Justice Story, in Martin v. Hunter's Lessee, ${ }^{8}$ but it has been repeatedly repudiated by the Supreme Court. The settled doctrine is that Congress, while it lacks authority to give the federal courts any jurisdiction beyond the boundaries prescribed in the Constitution, ${ }^{9}$ has no duty to confer all of the jurisdiction provided for in the Constitution upon any or all of the federal courts. ${ }^{10}$ This conclusion was reached on the reasoning that the creation of lower federal courts was entirely within the discretion of Congress, and so the jurisdiction to be conferred upon them was likewise wholly within the congressional discretion, provided, of course, that the constitutional limits were not exceeded. Whether or not this reasoning is sound, the result is too firmly established to be now questioned. Congress might, therefore, have created a system of federal courts without conferring jurisdiction of suits between citizens of different states upon any of them, and it may now take such jurisdiction from them.

Purpose of the Constitutional Provision for Federal

Jurisdiction Based upon Diversity of Citizenship

To sustain the constitutionality of the Norris Bill does not mean, however, that it should be enacted. The answer to that problem depends upon the desirability of the bill as a matter of

'U. S. Constitution, ART. III, § 2.

${ }^{8}$ I Wheat. 304,330 (U. S. I816).

${ }^{\circ}$ Marbury v. Madison, I Cranch 137 (U. S. I803).

${ }^{10}$ U. S. v. Hudson, 7 Cranch 32 (U. S. I8I2) ; Sheldon v. Sill, 8 How. $44 \mathrm{I}$ (U. S. I850) ; Kline v. Burke Construction Co., 260 U. S. 226, 43 Sup. Ct. 79 (1922). 
policy. In a consideration of this matter, the first step is to determine the purpose of the constitutional provision permitting jurisdiction upon this basis, and to consider the question whether this purpose is now of any consequence and whether it is being served by the jurisdiction as at present exercised.

There seems to be no disagreement as to the primary purpose of this provision for federal jurisdiction based upon diversity of citizenship. It was to provide, so far as possible, against injury to nonresident suitors because of local and sectional prejudice, which would be extremely likely to have an important effect in state courts. ${ }^{11}$ It is sometimes asserted that the "Fathers of the Constitution" regarded this branch of federal jurisdiction as of trifling importance. ${ }^{12}$ This may be true, but, if so, they were decidedly in error. It has proved an enormously important branch quantitatively, and its importance has no doubt exceeded the proportionate amount of federal litigation attributable to it. There has probably been no single factor which has had greater influence in encouraging the development of the sections of the country remote from financial centers than this branch of the federal jurisdiction. Investors living in and near the financial centers of the country would undoubtedly have been at a substantial disadvantage in litigation in the state courts of the more remote states. where they were contemplating investing their money. The pioneer has a great fear of, and hostility to, the creditor class, and the courts of his part of the country are just as much influenced by this feeling as any other branch of the social machinery, if, indeed, not more so. At any rate, even if there were actually no such influence, the investor fears it, and relies very largely, for the security of his investment, on the federal courts, to which he is now entitled to resort solely because of this provision for jurisdiction based upon diversity of citizenship.

Likewise, the business interests still fear the state courts. Capital is proverbially timorous, and its owners would still shrink from sending it into remote sections of the country if its only safeguard were in the state courts, which these capitalists-justi-

"Friendly, The Historic Basis of Diversity Jurisdiction (1928) $4 \mathrm{I}$ HARv. L. REv. 483 .

Ibid. 487 . 
fiably to a large degree, but at any rate, in fact-distrust. If the flow of capital from the financial centers to the less developed parts of the country is a desirable thing-and the contrary will hardly be seriously asserted-the federal courts, in so far as they do furnish a judicial system less influenced by local prejudice, and therefore regarded with more confidence by persons living away from states where their investments are to be made, still perform a very valuable function. To convince oneself of this, one need only reflect on the long history of the endeavor of various states to exclude foreign corporations who resorted to the federal courts, and the equally long and rather discouraging fight of these corporations to avoid this penalty. ${ }^{13}$ Certainly the business interests would not have continued this long struggle, especially with the handicap of several unfavorable decisions of the Supreme Court, had they not felt very keenly the importance of their right to sue in the federal courts.

The foregoing will hardly be controverted, even by the most enthusiastic advocates of the Norris Bill and of the policy of radical limitation of the jurisdiction of the federal courts, which it embodies. Their assertion is that this local prejudice is no longer existent. They argue that pioneer conditions of society have ceased, and, with them, the prejudice against the so-called moneyed classes.

There is undoubtedly a large measure of truth in this argument, but the disappearance of state, and especially sectional, prejudice, while no doubt greatly to be desired, is, as yet, very far from the fact. Undoubtedly, such prejudice is weakening, particularly in the younger generation, but it is still strong enough to influence the whole social fabric, including the local and state courts. The money-lender of the north and east now has a much better chance for justice in the local courts, in parts of the country remote from the financial centers, but there is still a real handicap, not only because of the economic factors, which, while much weak-

${ }^{13}$ Terral v. Burke Construction Co., 257 U. S. 529, 42 Sup. Ct. I88 (I922), finally settled that a state cannot revoke the authority to do business of a foreign corporation because the latter resorts to the federal courts. For many years, however, the position of the Supreme Court was to the contrary, and several decisions denying to corporations relief from such state action were specifically overruled in this case. 
ened, still have a certain influence, but even more because of state and sectional prejudice, which, while perhaps dying, is far from dead.

From this aspect there is indeed one rather serious criticism which can be made of the efficiency of the federal courts. While belonging to the national judicial system, the district courts and even the circuit courts of appeals are in fact largely local courts; the juries are drawn from the vicinity, and even the judge or judges are residents of the locality. Under these circumstances, it might seem that the federal courts would not in fact avoid local prejudice, even if they performed a certain useful function in that they are generally supposed to do so; but federal courts actually do avoid to a large extent the unfortunate effects of local prejudice, which are apt to bear so heavily on the state courts. No doubt this must be largely attributable to the psychological effect upon the judges of their being officers of the United States rather than merely of the local jurisdiction. Thete are, however, certain important advantages in the composition and procedure of the federal courts, to which their success in this and other matters must be very largely due.

\section{Advantages of the Federal Courts over the State Courts in Composition and Procedure}

One very important advantage which the federal courts enjoy over those of practically all the states is the method of appointment and removal of judges. In the state courts, with but few exceptions, the judges are elected. This has the unfortunate effect of throwing the state judiciary into politics, with its system of rewards and punishments far removed from standards of legal learning and judicial poise, and of compelling even those judges who are really provided with this most essential judicial equipment to engage to a greater or less extent in the political arena-activities which are most distasteful to such men, and for which they are in no way fitted. Furthermore, nearly all states provide a definite, and often an unfortunately short, term for judicial office. This means that the judges of both the higher and lower courts must periodically engage in a campaign for reëlection, and, in 
that campaign, faithfulness and efficiency in the discharge of their judicial duties are apt to have much less weight than many other qualities not particularly desirable for a person holding judicial office. It is happily true, of course, that these burdens are being lightened, in the cases of the best of our state judges, by action of the bar, and there is a definite progress toward higher standards in the selection of state judges. Nevertheless, the interdependence of the state judiciaries with politics is a source of constant danger and sometimes of positive harm.

Far different and far happier is the lot of the federal judge. The Constitution provides that he shall be chosen by appointment of the President (with the usual "advice and consent of the senate"), and, furthermore, that he is appointed for life and cannot be removed except by impeachment for misconduct. ${ }^{14}$ It has been proved repeatedly that an appointive bench is, on the average, of a considerably higher calibre than an elective bench, principally because the appointing power nearly always gives much more consideration to the qualities which are desirable for judicial office, but which are of little consequence where the office is elective, because of their inherent lack of popular appeal. Even more important is the fact that a federal judge is not constantly harrassed with periodical campaigns for reelection, nor with the necessity of building his political fences to take care of these occasions. Accordingly, no such calamities as the defeat of Justice Mitchell in Minnesota ${ }^{15}$ are impending with respect to our federal judiciary, though it is almost certain that many of the most valuable members of that body would have had difficulty in even being elected, and certainly in being reëlected. Here is a very tangible part of the explanation of the higher quality of the federal bench.

In the matter of trying cases, there are perhaps not such fundamental differences, and, for the most part, the differences

14 ArTICLE II, $\$ 2$ of the Constitution provides for the appointment of justices of the Supreme Court by the President, with the advice and consent of the senate, and the same rule is prescribed for other federal officers whose appointmint is not otherwise provided for; and this latter provision, of course, includes the other federal judges. ARTICLE III, \& I provides that all federal judges shall hold office "during good behavior".

${ }^{25}$ The late Dean Ames characterised the defeat for reelection of this extremely able justice of the Minnesota Supreme Court as a "national calamity". 
that exist are not definitely in favor of the federal procedure. There is, however, one difference which alone makes the federal court an infinitely superior tribunal, and that is the power which the federal judge has to comment upon the facts, ${ }^{16}$ This is undoubtedly a common law power, and is still used vigorously and effectively in England. ${ }^{17}$ It has, however, few relics in the legal systems of our states, most of which have, by their constitutions or statutes, evinced an almost morbid fear of the trial judge, who is forbidden to be much more than an animated automaton. If he dares to express the faintest idea of the particular case, or, in fact, says anything which will be understandable by the jury, it amounts to a reversible error. A more absurd and more unfortunate means for regulating trial präctice can hardly be imagined. Fortunately, the federal judge is still left this power, and it is small wonder, in view thereof, that litigants having meritorious cases, but cases which cannot be readily clarified to a jury, and particularly to a local jury, without the assistance which can be given by a competent judge skilled in weighing and interpreting the facts, flock to the federal courts wheneyer they can.

It is true that Senator Norris has approved another bill ${ }^{18}$ to take away this power to comment upon the evidence from the federal judges. So far as the writer knows, no respectable authority has commented on this latter bill except as utterly vicious. ${ }^{19}$ However, it is to be noted that even now this tremendous advantage of the federal courts cannot ordinarily be obtained by suitors, and particularly by those who most need them, except through the existing diversity jurisdiction.

In addition, it is to be noted that the provision of the Judicial Code, providing for interpleaders by insurance companies, ${ }^{20}$ would

${ }^{18}$ Vicksburg, etc., R. R. v. Putnam, II8 U. S. 545, 7 Sup. Ct. I (1886); United States v. Philadelphia \& Reading R. R., I23 U. S. II3, 8 Sup. Ct. 77 (I887); Lincoln v. Power, I5I U. S. 436, I4 Sup. Ct. 387 (I894).

${ }^{27}$ Davidson v. Stanley, 2 Man. \& G. 72 I (I84I) ; Solarte v. Melville, 7 B. \& C. 430 (1827) ; 2 Thompson, TrIALS (2d ed. I912) \$2292.

${ }^{28} \mathrm{~S}$. 1094 , 70th Congress, generally known as the Caraway Bill, which has been favorably reported by the Senate Judiciary Committee.

${ }^{10}$ See Note (19I8) 3I HARV. L. REv. IOIr, Of course, if Congress does, by legislation, remove all of the virtues of the federal cuurts, there is not much use in retaining this or any other jurisdiction of these courts.

${ }^{\infty} 43$ STAT. 976 (1925), 28 U. S. C. A. §41, par. 26 (1926). 
probably be affected by the Norris Bill. This provision has been of immense value in protecting insurers from being compelled to pay twice on the same policy. To lose this protection is a result which would certainly be most unjust. Many states do not have such a clear provision, and, if they do, there is still danger of the insurer being sued in two jurisdictions. While the Norris Bill does not purport to affect this provision of the Judicial Code, it is hard to see how the provision can stand after jurisdiction based on diversity of citizenship has been abolished, since the insurance provision really rests upon the same theory of jurisdiction.

\section{Limitations on the Diversity JuRisdiction of the Federal Courts}

Apparently, the basic argument for the abolition of the diversity jurisdiction of the federal courts is that it would greatly reduce the burden upon these courts. This is probably true, and yet it is submitted that there are already sufficient restrictions to accomplish this end, so far as it can properly be done. There are at least two statutory restrictions; one prohibiting suits in the federal courts on choses in action which have been assigned, unless the assignor could have brought suit in the federal courts ${ }^{21}$ (with certain exceptions), and the restriction on the federal courts against enjoining any action of state courts. ${ }^{22}$ Then there are restrictions which have been created by judicial action. A very important one is the rule that, where there is a plurality of plaintiffs or defendants, or both, a federal court has no jurisdiction unless each plaintiff could sue each defendant. ${ }^{23}$ This is at least a logical, though hardly necessary, doctrine; but not even this justification can be made for the settled doctrine that a resident of a territory or of the District of Columbia is not a resident of a state within the meaning of this provision ${ }^{24}$-thus, in effect,

${ }^{21} 36$ Stat. IOgI (Igri), 28 U. S. C. A. \$ 4I, par. 1 (1926). This restriction was upheld in Sheldon v. Sill, supra note Io.

${ }^{2} 36$ STAt. II62 (IgII), 28 U. S. C. A. $\$ 379$ (Ig26). See Kline v. Burke Construction Co., supra note Io.

${ }^{23}$ Strawbridge v. Curtiss, 3 Cranch 267 (U. S. 1806). This case was criticized in Louisville, etc., R. R. v. Letson, 2 How. 497 (U. S. I844), but the Supreme Court has always adhered to this doctrine.

a Hepburn and Dundas v. Ellzey, 2 Cranch 445 (U. S. I805); New Orleans v. Winter, I Wheat. 91 (U. S. 1816). 
keeping residents of these jurisdictions out of the federal courts, except where a federal question is involved. The only possible basis for this doctrine is the policy of restricting federal jurisdiction.

\section{JURISDiction with RESPECT to CoRporations}

There is, however, another restriction which many authorities have urged the federal courts to adopt, but which they have thus far refused to sanction. It is insisted that corporations should not be permitted to sue or be sued in the federal courts on the ground of diversity of citizenship. ${ }^{25}$ The federal courts have not adopted this doctrine, and yet it must be freely admitted that the theory upon which they have determined that corporations are proper litigants before them is not a very consistent or creditable one. It is based upon the theory of a "conclusive presumption" that the members of the corporation are citizens of the state in which it is incorporated, and that the corporation may sue or be sued as such. ${ }^{26}$ This theory is recognized by the courts themselves as a rather absurd fiction, and is not followed where it is not considered necessary to do so, $^{27}$ but the net result is that a corporation, for judicial purposes, is a citizen of the state in which it is incorporated. This view was squarely laid down in Louisville, etc., $R$. R. $\tau$. Letson, ${ }^{28}$ but the reasoning of that case was not adhered to, ${ }^{29}$ though its result was.

Admitting that the theory is unsatisfactory, yet if the result is correct the present rule should be followed. The question really is whether corporations should be permitted to sue and be sued in the federal courts, when the opposing litigant is a citizen of a state other than that in which the corporation is organized. It is objected that this treats the corporation as a citizen, and certainly

25 Frankfurter, op. cit. supra note 5, at 523; Warren, New Light on the History of the Federal Judiciary Act of 1789 (1923) 37 HARv. L. REv. 49, 89.

${ }^{\infty}$ Bank of United States v. Deveaux, 5 Cranch 6r (U. S. I809); Marshall v. B. \& O. R. R., I6 How. 314 (U. S. 1853).

${ }^{2 \pi}$ In Doctor v. Harrington, 196 U. S. 579, 25 Sup. Ct. 355 (1905), this presumption was not permitted to bar a stockholder's suit against a corporation organized in a state different from the plaintiff's actual residence.

${ }^{23}$ Supra note 23. Warren, op. cit. supra note 25, refers to the case as "This malignant decision".

${ }^{20}$ Marshall v. B. \& O. R. R., supra note 26. 
corporations are not citizens for all purposes. ${ }^{30}$ It is submitted, however, that the answer to the question just stated should be in the affirmative, as, in fact, the courts have answered it.

Considering the question from a theoretical standpoint, a corporation is certainly a legal person, and is a resident of the state where organized; and residence is the real test for citizenship in this diversity jurisdiction. If the law does indulge in any fiction in connection with business organizations, it consists in denying the personality of partnerships, rather than in recognizing that of corporations. In fact, as well as in law, a corporation is a person, ${ }^{31}$ and a resident of the state in which it is organized.

Looking at the question from the practical standpoint, a decision that corporations were not to be considered as within the purview of the diversity jurisdiction would be very unfortunate. The advantage of this jurisdiction to the business interests of the country has already been pointed out, ${ }^{32}$ and it has likewise been shown that this business advantage is reflected in benefits to the undeveloped parts of our country, in encouraging the investment of capital there.

Furthermore, it is common knowledge that interstate business is done very largely by corporations. Considered from the economic standpoint, a corporation is a device often valuable in small business but absolutely necessary in business operating on a large scale and over wide territory. It may be that we ought to discourage such business, but, if we are going to do so, we must submit to a great decrease, if not a practical cessation, in the development of the more remote parts of our country, and to a very considerable check on the volume of interstate business. Certainly it would seem that if these states do not want capital and business to come in from outside, they can largely prevent it by excluding foreign corporations, but to exclude foreign corporations, which have been admitted to do business in these states, from the federal courts would involve a most serious result. ${ }^{33}$

\footnotetext{
${ }^{30}$ Paul v. Virginia, 8 Wall. 168 (U. S. I868).

${ }^{31}$ Willis, The Doctrine of Sovereignty under the United States Constitution (1929) I5 VA. L. REv. 437, 445.

$\approx$ Stupra page I8I.

${ }^{33}$ Terral v. Burke Construction Co., supra note 3.
} 
Furthermore, corporations are certainly as subject to local and sectional prejudice as are individuals-indeed, rather more so. The exclusion of foreign corporations from the benefit of the diversity jurisdiction would therefore be directly contrary to the very purpose of this jurisdiction.

\section{The Doctrine of Swift v. Tyson}

Certain substantive doctrines of the federal courts, which have been developed in the exercise of the diversity jurisdiction, have, however, been vigorously criticized, and have been submitted as additional reasons for the abolition of this jurisdiction. Of these doctrines, the most important are those embodied in Szift v. Tyson ${ }^{34}$ and Gelpecke v. Dubuque. ${ }^{35}$ They are undoubtedly well settled, although it would be perfectly possible to abolish them by statute, without abolishing the jurisdiction in toto, and this has indeed been suggested. ${ }^{36}$

The doctrine of Swift $v$. Tyson is to the effect that Section 34 of the Judiciary Act of $1789^{37}$ does not require the federal courts to follow the judicial decisions of the state courts, even though the law of the state alone is in question. There are important exceptions to this rule in connection with the construction of state statutes and local rules of property, but these need not be considered in detail, since we are chiefly interested in the basic soundness of the doctrine. ${ }^{38}$

It is submitted that, apart from any historical questions, ${ }^{30}$ the doctrine is fundamentally sound. The basic fallacy which

s6 Pet. I (U. S. 1842).

$3_{\text {I }}$ Wall. I75 (U. S. I863).

${ }^{38}$ Newlin, op. cit. supra note 6.

states, except where the Constitution, treaties, or statutes of the United States otherwise require or provide, shall be regarded as rules of decision in trials at common law, in the courts of the United States, in cases where they apply."

${ }^{37}$ I STAT. 92 (I789), 28 U. S. C. $\$ 725$ (I928). "The laws of the several

$\approx$ Typical recent criticisms of the doctrine are Frankfurter, op. cit. supra note 5, at 526, and Johnson, State Late and the Federal Courts (1929) I7 Kr. L. J. 355 .

so Warren, op cit. supra note 25 , at 82 , has endeavored to show that Swift v. Tyson was not decided in accordance with the intention of the framers of the Judiciary Act of 1789 . 
ordinarily appears in attacks upon it is that the federal courts are foreign to the states. This is obviously a mistaken idea, for, if they really are foreign courts, we have a system of extra-territoriality much more wide-spread and serious than any which has ever prevailed in the Orient. If the federal courts have any right to sit in the states at all (and this applies to federal questions as well as questions of state law), they are sitting as domestic courts. When they are considering a question of state law, they have at least coördinate jurisdiction with the state courts, and are no more to be bound by the state court decisions than are the state courts by the federal decisions. In other words, we have two judicial systems, of equal jurisdiction, engaged in deciding the state law, and it is not surprising that they may occasionally disagree.

Is this a desirable situation? It is certainly not wholly so, in that it gives rise to a considerable diversity of judicial interpretation within a single state. The federal courts attempt to obviate this by giving very great weight to the state decisions, but they may perhaps be criticized as not following this rule with sufficient closeness. This diversity had a rather flagrant example in the recent case of Black and White Taxicab, etc., Co. v. Brown and Yellow Taxicab, etc., Co., ${ }^{40}$ where a settled principle of Kentucky law was overturned in the federal courts. It may be well contended that the Kentucky decisions should have been followed in this case, particularly as it can be argued that they constituted a rule of property in that state.

This diversity is, however, inherent in our dual system of government. For example, diversity of laws between two states, separated as they are by only an invisible line, is frequently just as troublesome as diversity of judicial decisions in a single state. Furthermore, even if the statute in question is construed as requiring the federal courts to follow the state decisions, it has, by its very terms, no relation whatsoever to equitable cases. ${ }^{41}$ Therefore, diversity of decisions in equity cases is inevitable and is, in

${ }^{80} 276$ U. S. 518,48 Sup. Ct. 404 (1928).

11 The statute is quoted in note 37 , and, it will be noted, refers only to "trials at common law". The federal courts are committed to the position that the Constitution compels the permanent separation of their law and equity jurisdiction. Pusey \& Jones Co. v. Hanssen, 26I U. S. $49 \mathrm{I}, 43$ Sup. Ct. 454 (1923). 
fact, just as troublesome as where it appears in common law cases. ${ }^{42}$

Nevertheless, it must be admitted that this diversity of judicial decision, introduced by Swift $v$. Tyson, constitutes a real disadvantage. There is, however, one contravening advantage, which, it is submitted, justifies the doctrine, with all its inconveniences, and that is the tendency which it has to eliminate local peculiarities of judicial interpretation. It is often urged that the state courts are likely to adhere tenaciously to their own view, and they often do attempt to do so. Nevertheless, the federal rule is almost invariably the superior rule, or at least the one which is followed by most jurisdictions, and the pressure of this condition generally, though often rather slowly, causes the state courts to conform. If they do not, the state legislatures not infrequently intervene in favor of the federal rule. ${ }^{43}$ Therefore, the rule, while it does sometimes lead to diversity of judicial interpretation within a single jurisdiction, tends eventually toward putting an end to this difficulty, and, furthermore, tends to minimize the other, and almost equally troublesome, form of diversity-that between different jurisdictions. While the doctrine should be rather strictly applied, and perhaps more so than at present, yet it is submitted that it should be retained.

\section{The Rúle of Gelpcke v. Dubuque}

The other important rule of the federal courts which has always been the subject of vigorous criticism is that of Gelpcke $v$. Dubuque. ${ }^{44}$ This rule is to the effect that, even in a case where

- Iir re James, I3I Fed. 401 (C. C. A. Ist, 1904), is a rather extreme example of the confusion which arises in equity cases. Here the court, which was sitting in bankruptcy (which is administered on equitable principles), disregarded a Massachusetts statute, although the transaction in question took place in that state and was concededly governed by Massachusetts law. Admitting (as seems probable) that the case was wrongly decided, yet it shows the possibility of even worse confusion than Swift v. Tyson can cause; and this source of confusion will continue, not only if the doctrine of Swift v. Tyson is abandoned, but even though the whole diversity jurisdiction of the federal courts is abolished.

43 The Negotiable Instruments Law, \$25, embodies the substantive rule laid down in Swift v. Tyson. That law having been adopted in New York, the state whose law was in question in that case, the legislature thus brought the law of that state into conformity with the federal rule.

* Supra note 35 . 
the federal courts consider themselves bound by the state decisions, they will not follow a change of those decisions, where such a change brings about a manifestly unfair result. In this particular case (and, indeed, in most of the cases where the rule has been applied) there was an issue of bonds by a state, or by one of its municipal corporations, which was valid, according to the state supreme court, at the time issued; but it was attempted to be invalidated by a decision, subsequent to the issue of the bonds, overruling the decisions in reliance upon which the bonds were purchased. The doctrine is undoubtedly somewhat hard to support theoretically, not only because it assumes that court decisions make the law (an assumption which is undoubtedly sound, but certainly is contrary to the usual theory as exemplified in Swift $v . T^{y}$ son $^{45}$ ), but because it has been finally decided (though after considerable oscillation) that such a change of judicial decisions does not raise any federal question. ${ }^{43}$ No attention is paid to the correctness of the state decisions, and the rule may, therefore, be criticized as somewhat arbitrary.

Despite any criticism which may be levelled at it, however, the rule works well. Gelpcke v. Dubuque and the cases following it have prevented what was, in fact, repudiation by the states of their honest debts. ${ }^{47}$ That this repudiation took the form of a change of judicial decision, does not change the fact that it was really a repudiation. No doubt there are many methods of repudiation which the courts cannot remedy, but that is a poor reason

\footnotetext{
${ }^{16}$ There is a dictum in Pine Grove v. Talcott, I9 Wall. 666,678 (U. S. I873), to the effect that a change of judicial decisions may constitute a violation by a state of the contracts clause of the Federal Constitution, and Muhlker v. N. Y., etc., R. R., 197 U. S. 544, 25 Sup. Ct. 522 (1905), is a square decision to the same effect. If this were correct, such a change of decisions would raise a federal question. However, it is clearly not correct, because a change of decisions is not the passage of a law, and it is only the passing of laws that comes within the contracts clause. The Supreme Court has therefore repudiated this doctrine, and, by the decision in Tidal Oil Co. v. Flanagan, 263 U. S. 444 , 44 Sup. Ct. 197 (1924), has finally settled that only legislative action of a state falls within the inhibition of the contracts clause. It follows that where a case like Gelpcke v. Dubuque comes up from a state court, no federal question is involved and the state decision must be followed. Railroad Co. v. McClure, io Wall. $5^{\text {II }}$ (U. S. I870). 3 II.

"See Thayer, The Case of Gelpcke v. Dubuque (I89I) 4 HARv. L. REv.
}

${ }^{25}$ See Rand, Swift v. Tyson versus Gelpcke v. Dubuque (I895) 8 Harv. L. REv. 328. 
for denying them the power to cure the situation where they can. There is no immediate danger of a widespread repudiation of public debt in this country, but circumstances may so change as again to make this a vital problem. In the meantime the doctrine of Gelpcke v. Dubuque is a safeguard, partial and inadequate though it may be, against such repudiation. It should therefore be retained, and it can only be retained, through the diversity jurisdiction of the federal courts, since, as already shown, such a change of judicial decision does not raise a federal question. ${ }^{4}$

\section{CONCLUSION}

The conclusion, therefore, seems clear that the jurisdiction of the federal courts based upon diversity of citizenship should be retained, and furthermore that it should not be limited in any major particular. To abolish it or to limit it radically, might, and probably would, reduce the burden on these courts, but the experiment is too dangerous to be justified: If, as has been shown, the exercise of this jurisdiction is rendering a valuable service to the country as a whole, then, if the burden on the courts is too great, the proper solution lies in an increase in the number of courts. There is no danger that the Supreme Court will be burdened by this jurisdiction, since no case of this sort can now come before the Supreme Court without its own consent. ${ }^{49}$

It may be admitted that in some cases the jurisdiction is still too broad, but the remedy must be largely with the courts themselves. It does. seem that, while they should be permitted to retain the doctrine of Swift $v$. Tyson, they ought to limit it more severely, and it might well be that a more rigid scrutiny of corporations formed merely for the purpose of suing in the federal courts would be distinctly desirable. ${ }^{50}$ However, it would be bet-

${ }^{*}$ Railroad Co. v. McClure, supra note 46.

- Under the provisions of the Act of February 13, I925, 43 Stat. 938 (I925), 28 U. S. C. $\$ 345$ et seq. (I928), there is no appeal as of right to the Supreme Court from the lower federal courts except in a. few narrow. classes of cases, all of which involve federali questions.

${ }^{\text {so }}$ Black \& White Taxical, etc., Co. v. Brown \& Yellow Taxicab, etc, Co., supra note 40, was a rather flagrant example of this sort of corporation hocuspocus. The court applied its settled: doctrine that this is proper, so long: as the change of state of incorporation is actually made, even though the sole purpose is to get into the federal courts. Of course, if the change is merely colorable, 
ter, for the most part, to leave these matters to the courts themselves.

If it be urged that this leaves no room for a perfecting of the federal judicial system by legislation, it may be readily answered that all the reforming zeal of Congress may be properly utilized in other directions. In the first place, and before Congress does anything else, it should pass the Uniformity Procedure Bill, ${ }^{51}$ which has been before it for years. The passage of this one measure, thus getting rid of that most wretched piece of legislation, the Conformity Act, ${ }^{52}$ would do more for the improvement of the federal judicial system than anything else which could be done. Then, if Congress' zeal is unabated, it might turn its attention to the relief of the unfortunate situation arising out of the federal courts' inability to use state remedies in equity suits. ${ }^{53}$ It must be conceded that this difficulty is not altogether the fault of Congress and cannot be wholly remedied, because of the settled doctrine of the federal courts that the separation of law and equity is sanctified in perpetuity by the Constitution. Nevertheless, it would seem that at least it might be enacted that creditors' bills could be brought in the federal courts, without the formality of obtaining a judgment at law.

There is still one other thing that can be done. That is to pass the bill, already introduced, ${ }^{54}$ providing that the federal courts shall have jurisdiction to give declaratory judgments. This too would be an immediate and valuable reform. Congress should give its immediate attention to the enactment of these practically undisputed reforms of the federal judicial system, rather than interfere with the largely satisfactory situation as to the diversity jurisdiction of the federal courts.

the case will be dismissed as not really involving a controversy between citizens of different states. Miller \& Lux, Inc., v. East Side Canal, etc., Co., 2r I U. S. 293, 29 Sup. Ct. III (I908). It is submitted, however, that the court might well reconsider the soundness of permitting a change of corporate domicile merely for the purpose of getting into the federal courts.

${ }^{\circ} \mathrm{S}$. 2061, 68th Congress. See Taft, Uniformity of Procedure in the Federal Courts (1926) I2 A. B. A. J. 20.

${ }^{63}$ I7 STAT. I97 (1872) 28 U. S. C. $\$ 724$ (I928).

* Pusey \& Jones Co. v. Hanssen, supra note $4 \mathrm{r}$.

*4 H. R. 5623, 70th Congress. 